\section{JURNAL EKONOMI EFEKTIF}

ISSN : $2622-8882$, E-ISSN : 2622-9935

Jurnal Ekonomi Efektif, Vol. 2, No. 3, April 2020

@Prodi Manajemen Fakultas Ekonomi Universitas

Pamulang

\title{
PENGARUH KEPEMIMPINAN DAN KOMUNIKASI TERHADAP KINERJA GURU PADA SMAN 6 KOTA TANGERANG SELATAN
}

\author{
Sutrisno $^{1^{*}, \text { Mulyadi }^{2}}$ \\ Universitas Pamulang \\ dosen0035@unpam.ac.id*
}

\begin{abstract}
ABSTRAK
Penelitian ini bertujuan untuk mengetahui pengaruh kepemimpinan dan komunikasi terhadap kinerja guru pada SMAN 6 Kota Tangerang Selatan. Metode yang digunakan adalah explanatory research dengan teknik analisis menggunakan analisis statistik dengan pengujian regresi, korelasi, determinasi dan uji hipotesis.

Hasil penelitian ini kepemimpinan berpengaruh signifikan terhadap kinerja guru sebesar $63,6 \%$, uji hipotesis diperoleh $t$ hitung $>\mathrm{t}$ tabel atau $(8,143>2,024)$. Komunikasi berpengaruh signifikan terhadap kinerja guru sebesar 49,6\%, uji hipotesis diperoleh thitung > $\mathrm{t}$ tabel atau $(6,111>2,024)$. Kepemimpinan dan komunikasi secara simultan berpengaruh signifikan terhadap kinerja guru dengan persamaan regresi $\mathrm{Y}=7,267+0,485 \mathrm{X} 1+0,347 \mathrm{X} 2$ dan kontribusi pengaruh sebesar 73,4\%, uji hipotesis diperoleh $\mathrm{F}$ hitung $>\mathrm{F}$ tabel atau $(51,165$ $>2,860$ ).
\end{abstract}

Kata Kunci: Kepemimpinan, Komunikasi, Kinerja Guru

\begin{abstract}
This study aims to determine the effect of leadership and communication on teacher performance at SMAN 6 Kota Tangerang Selatan. The method used is explanatory research with analytical techniques using statistical analysis with regression testing, correlation, determination and hypothesis testing.

The results of this study leadership has a significant effect on teacher performance by $63.6 \%$, the hypothesis test obtained $t$ count $>t$ table or $(8,143>2,024)$. Communication has a significant effect on teacher performance by 49.6\%, the hypothesis test obtained $t$ count $>t$ table or (6.111> 2.024). Leadership and communication simultaneously have a significant effect on teacher performance with a regression equation $Y=7.267+0.485 X 1+0.347 X 2$ and the contribution of influence is $73.4 \%$, the hypothesis test is obtained $F$ count $>F$ table or $(51.165>2.860)$.
\end{abstract}

Keywords: Leadership, Communication, Teacher Performance 


\section{PENDAHULUAN}

\section{A. Latar Belakang Masalah}

Sekolah menjadi kebutuhan mendasar bagi semua orang, apalagi dizaman yang semakin mengedepankan pendidikan sebagai salah satu tolok ukur dan penilaiannya ini. Sekolah dianggap sebagai rumah kedua untuk mendapatkan pendidikan setelah pendidikan pertama didapat melalui rumah dan orang tua. Sekolah bisa diartikan sebagai tempat didikan bagi anak anak yang tujuannya adalah mengajarkan anak agar mampu untuk memajukan bangsa, sekolah diartikan pula sebagai sebuah lembaga yang dirancang untuk mengajar siswa dibawah pengawasan guru. Kepemimpinan merupakan tulang punggung pengembangan organisasi, karena tanpa kepemimpinan yang baik akan sulit untuk mencapai tujuan organisasi.

Menurut Garl Yukl (2015:9) Kepemimpinan adalah proses mempengaruhi orang lain untuk memahami dan menyetujui apa yang dibutuhkan dalam melaksanakan tugas dan bagaimana melaksanakan tugas itu, serta proses untuk memfasilitasi upaya individu dan kolektif guna mencapai tujuan bersama. Sebagai makhluk sosial yang tidak dapat melepaskan diri dari jalinan relasi sosial, dimana manusia selalu akan mengadakan kontak sosial, yaitu selalu berhubungan dengan orang lain. Dalam dunia pendidikan tidak terlepas dari kepemimpinan dan kegiatan komunikasi. Mereka dapat menggunakan berbagai media komunikasi yang ada, baik konvensional maupun yang elektronik sebagai sarana penyimpanan pesan pesan. Bahkan sebagian besar dari waktu tersebut digunakan untuk berkomunikasi. Menurut Fieske dalam Poppy Ruliana (2012:1) komunikasi adalah salah satu aktivitas manusia dan suatu topik yang amat sering diperbincangkan sehingga kata komunikasi memiliki variasi definisi dan rujukan yang tidak terhingga. Dalam kehidupan sehari hari disadari atau tidak komunikasi adalah bagian dari kehidupan manusia itu sendiri. Manusia sejak dilahirkan sudah berkomunikasi dengan lingkungannya. Suatu jalinan dapat menentukan harmonisasi, salah satu bentuk yang dapat menentukan keharmonisan antar manusia tersebut adalah komunikasi interpersonal.

Pada umumnya komunikasi interpersonal terjadi karena pada hakikatnya setiap manusia suka berkomunikasi dengan manusia lain, karena itu setiap orang selalu berusaha agar mereka lebih dekat satu sama lain, Komunikasi sangat penting bagi kebahagiaan hidup manusia, kegiatan komunikasi tersebut dilakukan sebagai upaya memenuhi kebutuhan bersekutu dengan orang lain.

Berdasarkan data tersebut maka dapat di ketahui terjadi penurunan kinerja guru dimana kinerja guru menurut Supardi (2014:54) kinerja guru merupakan kemampuan seorang guru dalam melaksanakan tugas pembelajaran di madrasah dan bertanggung jawab atas peserta didik dibawah bimbingannya dengan meningkatkan prestasi belajar peserta didik. Oleh karena itu, kinerja guru itu dapat diartikan sebagai suatu kondisi yang menunjukan kemampuan seorang guru dalam menjalankan tugasnya di madrasah serta menggambarkan adanya suatu perbuatan yang ditampilkan guru dalam atau selama melakukan aktivitas pembelajaran. Guru yang memiliki kinerja baik dan profesional dalam implementasi kurikulum memiliki ciri-ciri mendesain program.

Berdasarkan latar belakang di atas, maka penulis tertarik melakukan penelitian dengan judul: "PENGARUH KEPEMIMPINAN DAN KOMUNIKASI TERHADAP KINERJA GURU PADA SMAN 6 KOTA TANGERANG SELATAN".

\section{B. Perumusan Permasalahan Penelitian}

1. Adakah pengaruh secara parsial antara kepemimpinan terhadap kinerja guru pada SMAN 6 Kota Tangerang Selatan? 
2. Adakah pengaruh secara parsial antara komunikasi terhadap kinerja guru pada SMAN 6 Kota Tangerang Selatan?

3. Adakah pengaruh secara simultan antara kepemimpinan dan komunikasi terhadap kinerja guru pada SMAN 6 Kota Tangerang Selatan?

\section{Manfaat Penelitian}

1. Untuk mengetahui pengaruh secara parsial antara kepemimpinan terhadap kinerja guru pada SMAN 6 Kota Tangerang Selatan..

2. Untuk mengetahui pengaruh secara parsial antara komunikasi terhadap kinerja guru pada SMAN 6 Kota Tangerang Selatan.

3. Untuk mengetahui pengaruh secara simultan antara kepemimpinan dan komunikasi terhadap kinerja guru pada SMAN 6 Kota Tangerang Selatan

\section{METODE PENELITIAN}

Populasi dalam penelitian ini berjumlah 40 responden/guru SMAN 6 Kota Tangerang Selatan. Teknik pengambilan sampling dalam penelitian ini adalah samplel jenuh, dimana semua anggota populasi dijasikan sebagai sampel. Dengan demikian sampel dalam penelitian ini berjumlah 40 responden/guru. Jenis penelitian yang dipakai adalah asosiatif, dimana tujuannya adalah untuk mengetahui pengaruh antara variabel bebas terhadap variabel terikat baik parsial maupun simultan. Dalam menganalisis data digunakan uji instrumen, uji asumsi klasik, regresi, koefisien determinasi dan uji hipotesis.

\section{HASIL PENELITIAN DAN PEMBAHASAN}

\section{A. Hasil Penelitian}

\section{Analisis Deskriptif}

Pada pengujian ini digunakan untuk mengetahui skor minimum dan maksimum, mean score dan standar deviasi dari masing-masing variabel. Adapun hasilnya sebagai berikut:

Tabel 1. Hasil Analisis Descriptive Statistic

\section{Descriptive Statistics}

\begin{tabular}{|c|c|c|c|c|c|}
\hline & $\mathrm{N}$ & Minimum & $\begin{array}{c}\text { Maximu } \\
\mathrm{m}\end{array}$ & Mean & Std. Deviation \\
\hline Kepemimpinan (X1) & 40 & 33 & 48 & 38.68 & 4.474 \\
\hline Komunikasi (X2) & 40 & 31 & 48 & 38.32 & 4.028 \\
\hline Kinerja Guru (Y) & 40 & 33 & 47 & 39.33 & 3.696 \\
\hline Valid N (listwise) & 40 & & & & \\
\hline
\end{tabular}

Kepemimpinan diperoleh varians minimum sebesar 33 dan varians maximum 48 dengan mean score sebesar 3,86 dengan standar deviasi 4,474. Komunikasi diperoleh varians minimum sebesar 31 dan varians maximum 48 dengan mean score sebesar 3,83 dengan standar deviasi 4,028. Kinerja guru diperoleh varians minimum sebesar 33 dan varians maximum 47 dengan mean score sebesar 3,93 dengan standar deviasi 3,696.

2. Analisis Verifikatif.

Pada analisis ini dimaksudkan untuk mengetahui pengaruh variabel independen terhadap variabel dependen. Adapun hasil pengujian sebagai berikut:

\section{a. Analisis Regresi Linier Sederhana dan Berganda}

Uji regresi ini dimaksudkan untuk mengetahui perubahan variabel dependen jika variabel independen mengalami perubahan. Adapun hasil pengujiannya sebagai berikut: 
Tabel 2. Hasil Uji Regresi Linier Sederhana Variabel Kepemimpinan (X1)

\section{Coefficients ${ }^{\mathrm{a}}$}

\begin{tabular}{|c|c|c|c|c|c|}
\hline \multirow[b]{2}{*}{ Model } & \multicolumn{2}{|c|}{$\begin{array}{l}\text { Unstandardized } \\
\text { Coefficients }\end{array}$} & \multirow[t]{2}{*}{$\begin{array}{c}\text { Standardize } \\
\mathrm{d} \\
\text { Coefficient } \\
\text { s } \\
\text { Beta } \\
\end{array}$} & \multirow[b]{2}{*}{$\mathrm{t}$} & \multirow[b]{2}{*}{ Sig. } \\
\hline & $\mathrm{B}$ & Std. Error & & & \\
\hline $1 \quad$ (Constant) & 13.853 & 3.149 & & 4.400 & .000 \\
\hline $\begin{array}{l}\text { Kepemimpinan } \\
\text { (X1) }\end{array}$ & .659 & .081 & .797 & 8.143 & .000 \\
\hline
\end{tabular}

a. Dependent Variable: Kinerja Guru (Y)

Berdasarkan hasil pengujian pada tabel di atas, diperoleh persamaan regresi $\mathrm{Y}=$ $13,853+0,659 \mathrm{X} 1$. Dari persamaan tersebut dijelaskan sebagai berikut:

1) Konstanta sebesar 13,853 diartikan jika kepemimpinan tidak ada, sementara variabel lain konstan, maka telah terdapat nilai kinerja guru sebesar 13,853 point.

Koefisien regresi kepemimpinan sebesar 0,659, angka ini positif artinya setiap ada peningkatan kepemimpinan sebesar 0,659 maka kinerja guru juga akan mengalami peningkatan sebesar 0,659 point.

Tabel 3. Hasil Uji Regresi Linier Sederhana Variabel Komunikasi (X2)

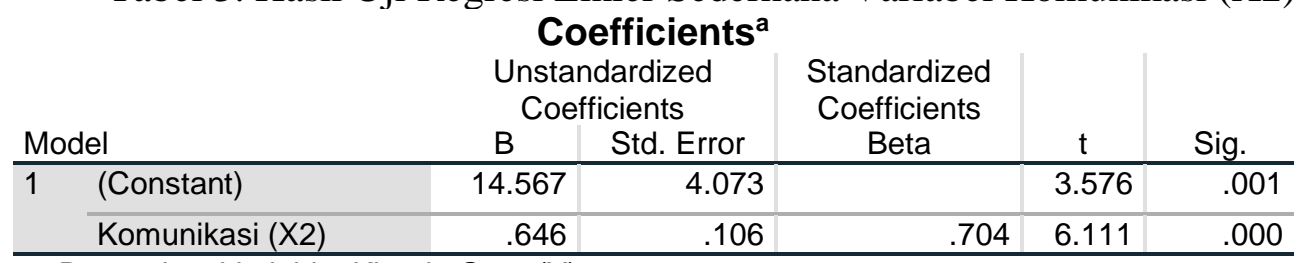

a. Dependent Variable: Kinerja Guru (Y)

Berdasarkan hasil pengujian pada tabel di atas, diperoleh persamaan regresi $\mathrm{Y}=$ 14,567 + 0,646X2. Dari persamaan tersebut dijelaskan sebagai berikut:

1) Konstanta sebesar 14,567 diartikan jika komunikasi tidak ada, sementara variabel lain konstan, maka telah terdapat nilai kinerja guru sebesar 14,567 point.

2) Koefisien regresi komunikasi sebesar 0,646, angka ini positif artinya setiap ada peningkatan komunikasi sebesar 0,646 maka kinerja guru juga akan mengalami peningkatan sebesar 0,646 point.

Tabel 4. Hasil Pengujian Regresi Linier Berganda

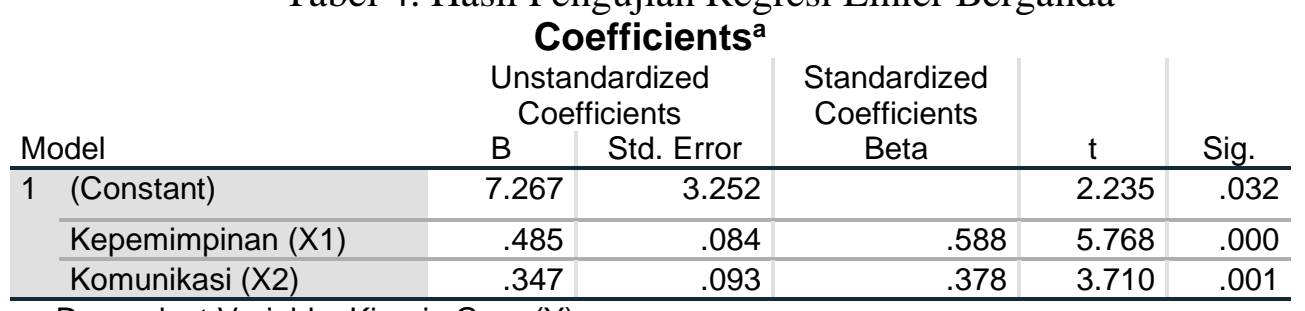

a. Dependent Variable: Kinerja Guru $(\mathrm{Y})$

Berdasarkan hasil pengujian pada tabel di atas, diperoleh persamaan regresi $\mathrm{Y}=$ $7,267+0,485 X 1+0,347 X 2$. Dari persamaan tersebut dijelaskan sebagai berikut:

1) Konstanta sebesar 7,267 diartikan jika kepemimpinan dan komunikasi tidak ada, maka telah terdapat nilai kinerja guru sebesar 7,267 point.

2) Koefisien regresi kepemimpinan sebesar 0,485 , angka ini positif artinya setiap ada peningkatan kepemimpinan sebesar 0,485 maka kinerja guru juga akan mengalami peningkatan sebesar 0,485 point.

3) Koefisien regresi komunikasi sebesar 0,347, angka ini positif artinya setiap ada peningkatan komunikasi sebesar 0,347 maka kinerja guru juga akan mengalami peningkatan sebesar 0,347 point. 


\section{b. Analisis Koefisien Korelasi}

Analisis koefisien korelasi dimaksudkan untuk mengetahui tingkt kekuatan hubungan dari variabel independen terhadap variabel dependen baik secara parsial maupun simultan. Adapun hasil pengujian sebagai berikut:

Tabel 5. Hasil Uji Koefisien Korelasi Kepemimpinan Terhadap Kinerja Guru.

Correlations $^{\text {b }}$

\begin{tabular}{llr|r} 
& & $\begin{array}{c}\text { Kepemimpinan } \\
(\mathrm{X} 1)\end{array}$ & \multicolumn{1}{c}{ Kinerja Guru (Y) } \\
\hline Kepemimpinan (X1) & Pearson Correlation & 1 & $.797^{* *}$ \\
\cline { 2 - 4 } & Sig. (2-tailed) & & .000 \\
\hline Kinerja Guru (Y) & Pearson Correlation & $.797^{* *}$ & 1 \\
\cline { 2 - 4 } & Sig. (2-tailed) & .000 & \\
\hline
\end{tabular}

**. Correlation is significant at the 0.01 level (2-tailed).

b. Listwise $\mathrm{N}=40$

Berdasarkan hasil pengujian diperoleh nilai korelasi sebesar 0,797 artinya kepemimpinan memiliki hubungan yang kuat terhadap kinerja guru.

Tabel 6. Hasil Uji Koefisien Korelasi Komunikasi Terhadap Kinerja Guru.

\section{Correlations $^{\mathrm{b}}$}

\begin{tabular}{llr|r} 
& & $\begin{array}{c}\text { Komunikasi } \\
(\mathrm{X} 2)\end{array}$ & Kinerja Guru (Y) \\
\hline Komunikasi (X2) & Pearson Correlation & 1 & $.704^{* *}$ \\
\cline { 2 - 4 } & Sig. (2-tailed) & & .000 \\
\hline Kinerja Guru (Y) & Pearson Correlation & $.704^{* *}$ & 1 \\
\cline { 2 - 4 } & Sig. (2-tailed) & .000 & \\
\hline
\end{tabular}

**. Correlation is significant at the 0.01 level (2-tailed).

b. Listwise $\mathrm{N}=40$

Berdasarkan hasil pengujian diperoleh nilai korelasi sebesar 0,704 artinya komunikasi memiliki hubungan yang kuat terhadap kinerja guru.

Tabel 7. Hasil Pengujian Koefisien Korelasi Kepemimpinan dan Komunikasi secara simultan Terhadap Kinerja Guru.

\section{Model Summary}

\begin{tabular}{|c|c|c|c|c|}
\hline Model & $\mathrm{R}$ & R Square & $\begin{array}{l}\text { Adjusted R } \\
\text { Square }\end{array}$ & $\begin{array}{l}\text { Std. Error of the } \\
\text { Estimate }\end{array}$ \\
\hline 1 & $.857^{\mathrm{a}}$ & .734 & .720 & 1.955 \\
\hline
\end{tabular}

a. Predictors: (Constant), Komunikasi (X2), Kepemimpinan (X1)

Berdasarkan hasil pengujian diperoleh nilai korelasi sebesar 0,857 artinya kepemimpinan dan komunikasi secara simultan memiliki hubungan yang sangat kuat terhadap kinerja guru.

\section{c. Analisis Koefisien Determinasi}

Analisis koefisien determinasi dimaksudkan untuk mengetahui besarnya persentase pengaruh dari variabel independen terhadap variabel dependen baik secara parsial maupun simultan. Adapun hasil pengujian sebagai berikut:

Tabel 8. Hasil Pengujian Koefisien Determinasi Kepemimpinan Terhadap Kinerja Guru.

\section{Model Summary}

\begin{tabular}{|c|c|c|c|c|}
\hline \multirow[b]{2}{*}{ Sodd } & & \multirow[b]{2}{*}{$\begin{array}{l}\text { Std. Error of the } \\
\text { Estimate }\end{array}$} \\
\hline & $\mathrm{R}$ & R Square & $\begin{array}{l}\text { Adjusted R } \\
\text { Square }\end{array}$ & \\
\hline 1 & $797^{a}$ & .636 & .626 & 2.260 \\
\hline
\end{tabular}

a. Predictors: (Constant), Kepemimpinan (X1)

Berdasarkan hasil pengujian diperoleh nilai determinasi sebesar 0,636 artinya kepemimpinan memiliki kontribusi pengaruh sebesar 63,6\% terhadap kinerja guru. 
Tabel 9. Hasil Pengujian Koefisien Determinasi Komunikasi Terhadap Kinerja Guru.

\section{Model Summary}

\begin{tabular}{|c|c|c|c|c|}
\hline Model & $\mathrm{R}$ & R Square & $\begin{array}{l}\text { Adjusted R } \\
\text { Square }\end{array}$ & $\begin{array}{l}\text { Std. Error of the } \\
\text { Estimate }\end{array}$ \\
\hline$\overline{1}$ & $.704^{a}$ & .496 & .482 & 2.659 \\
\hline
\end{tabular}

Berdasarkan hasil pengujian diperoleh nilai determinasi sebesar 0,496 artinya komunikasi memiliki kontribusi pengaruh sebesar 49,6\% terhadap kinerja guru.

Tabel 10. Hasil Pengujian Koefisien Determinasi Kepemimpinan dan Komunikasi

Terhadap Kinerja Guru.

\section{Model Summary}

\begin{tabular}{|c|c|c|c|c|}
\hline Model & $\mathrm{R}$ & R Square & $\begin{array}{l}\text { Adjusted R } \\
\text { Square }\end{array}$ & $\begin{array}{l}\text { Std. Error of the } \\
\text { Estimate }\end{array}$ \\
\hline 1 & $.857^{a}$ & .734 & .720 & 1.955 \\
\hline
\end{tabular}

Berdasarkan hasil pengujian diperoleh nilai determinasi sebesar 0,734 artinya kepemimpinan dan komunikasi secara simultan memiliki kontribusi pengaruh sebesar $73,4 \%$ terhadap kinerja guru, sedangkan sisanya sebesar $26,6 \%$ dipengaruhi faktor lain.

\section{d. Uji Hipotesis}

\section{Uji hipotesis Parsial (Uji t)}

Pengujian hipotesis dengan uji t digunakan untuk mengetahui hipotesis parsial mana yang diterima.

Hipotesis pertama: Terdapat pengaruh yang signifikan antara kepemimpinan terhadap kinerja guru.

Tabel 11. Hasil Uji Hipotesis Kepemimpinan Terhadap Kinerja Guru.

\begin{tabular}{|c|c|c|c|c|c|c|}
\hline \multirow{3}{*}{\multicolumn{2}{|c|}{ Model }} & \multicolumn{3}{|c|}{ Coefficients $^{a}$} & \multirow[b]{3}{*}{$\mathrm{t}$} & \multirow[b]{3}{*}{ Sig. } \\
\hline & & \multicolumn{2}{|c|}{$\begin{array}{l}\text { Unstandardized } \\
\text { Coefficients }\end{array}$} & \multirow{2}{*}{$\begin{array}{c}\text { Standardized } \\
\text { Coefficients } \\
\text { Beta } \\
\end{array}$} & & \\
\hline & & $\mathrm{B}$ & Std. Error & & & \\
\hline 1 & (Constant) & 13.853 & 3.149 & & 4.400 & .000 \\
\hline & Kepemimpinan (X1) & .659 & .081 & .797 & 8.143 & .000 \\
\hline
\end{tabular}

a. Dependent Variable: Kinerja Guru $(\mathrm{Y})$

Berdasarkan hasil pengujian pada tabel di atas, diperoleh nilai $\mathrm{t}$ hitung $>\mathrm{t}$ tabel atau $(8,143>2,024)$, dengan demikian hipotesis pertama yang diajukan bahwa terdapat pengaruh yang signifikan atara kepemimpinan terhadap kinerja guru diterima.

Tabel 12. Hasil Uji Hipotesis Komunikasi Terhadap Kinerja Guru.

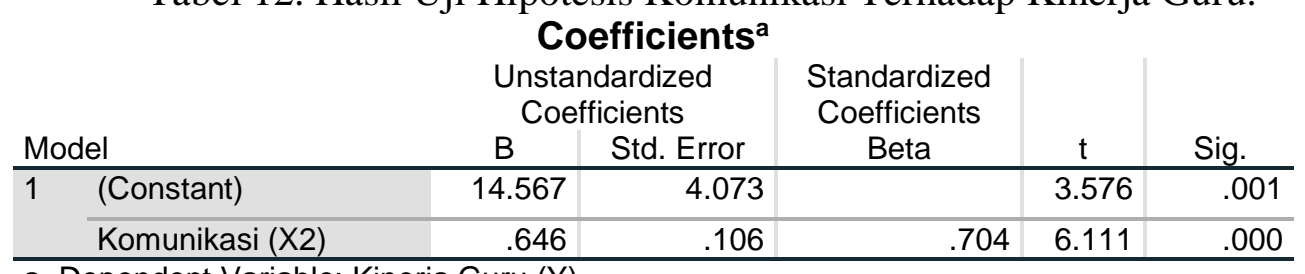

a. Dependent Variable: Kinerja Guru (Y)

Berdasarkan hasil pengujian pada tabel di atas, diperoleh nilai $\mathrm{t}$ hitung $>\mathrm{t}$ tabel atau $(6,111>2,024)$, dengan demikian hipotesis kedua yang diajukan bahwa terdapat pengaruh yang signifikan atara komunikasi terhadap kinerja guru diterima.

\section{Uji Hipotesis Simultan (Uji F)}

Pengujian hipotesis dengan uji $\mathrm{F}$ digunakan untuk mengetahui hipotesis simultan yang mana yang diterima.

Hipotesis ketiga Terdapat pengaruh yang signifikan antara kepemimpinan dan komunikasi terhadap kinerja guru. 
Tabel 13. Hasil Uji Hipotesis Kepemimpinan dan Komunikasi Terhadap Kinerja Guru. ANOVA $^{a}$

\begin{tabular}{ll|r|r|r|r|r} 
Model & & Sum of Squares & df & Mean Square & \multicolumn{1}{c}{ F } & Sig. \\
\hline 1 & Regression & 391.293 & 2 & 195.646 & 51.165 & $.000^{\mathrm{b}}$ \\
\cline { 2 - 7 } & Residual & 141.482 & 37 & 3.824 & & \\
\cline { 2 - 7 } & Total & 532.775 & 39 & & & \\
\hline
\end{tabular}

Berdasarkan hasil pengujian pada tabel di atas, diperoleh nilai $\mathrm{F}$ hitung $>\mathrm{F}$ tabel atau $(51,165>2,860)$, dengan demikian hipotesis ketiga yang diajukan bahwa terdapat pengaruh yang signifikan atara kepemimpinan dan komunikasi terhadap kinerja guru diterima.

\section{B. Pembahasan}

\section{Pengaruh Kepemimpinan Terhadap Kinerja Guru}

Kepemimpinan berpengaruh signifikan terhadap kinerja guru dengan diperoleh persamaan regresi $\mathrm{Y}=13,853+0,659 \mathrm{X} 1$, nilai korelasi sebesar 0,797 atau memiliki hubungan yang kuat dengan kontribusi pengaruh sebesar 63,6\%. Pengujian hipotesis diperoleh nilai t hitung $>\mathrm{t}$ tabel atau $(8,143>2,024)$. Dengan demikian hipotesis pertama yang diajukan bahwa terdapat berpengaruh signifikan antara kepemimpinan terhadap kinerja guru diterima.

\section{Pengaruh Komunikasi Terhadap Kinerja Guru}

Komunikasi berpengaruh signifikan terhadap kinerja guru dengan diperoleh persamaan regresi $\mathrm{Y}=14,567+0,646 \mathrm{X} 2$, nilai korelasi sebesar 0,704 atau memiliki hubungan yang kuat dengan kontribusi pengaruh sebesar $49,6 \%$. Pengujian hipotesis diperoleh nilai t hitung $>\mathrm{t}$ tabel atau $(6,111>2,024)$. Dengan demikian hipotesis kedua yang diajukan bahwa terdapat berpengaruh signifikan antara komunikasi terhadap kinerja guru diterima.

\section{Pengaruh Kepemimpinan dan Komunikasi Terhadap Kinerja Guru}

Kepemimpinan dan komunikasi berpengaruh signifikan terhadap kinerja guru dengan diperoleh persamaan regresi $\mathrm{Y}=7,267+0,485 \mathrm{X} 1+0,347 \mathrm{X} 2$, nilai korelasi sebesar 0,857 atau memiliki hubungan yang kuat dengan kontribusi pengaruh sebesar $73,4 \%$ sedangkan sisanya sebesar $26,6 \%$ dipengaruhi faktor lain. Pengujian hipotesis diperoleh nilai $\mathrm{F}$ hitung $>\mathrm{F}$ tabel atau $(51,165>2,860)$. Dengan demikian hipotesis ketiga yang diajukan bahwa terdapat berpengaruh signifikan antara kepemimpinan dan komunikasi terhadap kinerja guru diterima.

\section{PENUTUP}

\section{A. Kesimpulan}

1. Kepemimpinan berpengaruh signifikan terhadap kinerja guru dengan kontribusi pengaruh sebesar $63,6 \%$. Uji hipotesis diperoleh nilai $t$ hitung $>\mathrm{t}$ tabel atau $(8,143>$ $2,024)$.

2. Komunikasi berpengaruh signifikan terhadap kinerja guru dengan kontribusi pengaruh sebesar 49,6\%. Uji hipotesis diperoleh nilai t hitung > t tabel atau $(6,111>2,024)$.

3. Kepemimpinan dan komunikasi berpengaruh signifikan terhadap kinerja guru dengan kontribusi pengaruh sebesar 73,4\% sedangkan sisanya sebesar $26,6 \%$ dipengaruhi faktor lain. Uji hipotesis diperoleh nilai $\mathrm{F}$ hitung $>\mathrm{F}$ tabel atau $(51,165>2,860)$.

\section{B. Saran}

Pemimpin dalam melakukan keputusan yang menyangkut kepentingan guru, harus terlebih dahulu melakukan konsolidasi dan melibatkan seluruh karyawan. Komunikasi terkait tugas dan fungsi guru hendaknya disampaikan dengan lebih jelas dan terperinci 
sehingga tidak ada salah pengertian dalam menafsirkan instruksi yang diberikan oleh pimpinan

Perusahaan harus melakukan evaluasi kinerja kerja berkala terhadap para guru, dalam hal ini para atasan dan pemilik perusahaan diharapkan dapat mengkomunikasikan harapan serta arahan mereka dengan lebih baik kepada para guru, sehingga perbedaan pendapat dapat diluruskan dan karyawan mengerti dan memahami keinginan dan tujuan lembaga dengan sebaik-baiknya

\section{DAFTAR PUSTAKA}

A.A. Anwar Prabu Mangkunegara (2015), Manajamen Sumber Daya Manusia Perusahaan, PT Remaja Rosdakarya, Bandung.

Algifari (2015). Analisis Regresi untuk Bisnis dan Ekonomi. Yogyakarta: BPFE.

Handoko T. Hani, (2017), Manajemen Personalia dan Sumber Daya Manusia, edisi kedua, BPFE, Yogyakarta.

Hasibuan, Malayu SP (2016), Manajemen Sumber Daya Manusia, Edisi Revisi, Penerbit Bumi Aksara, Jakarta.

Imam Ghozali (2017). Aplikasi Analisis Multivariate Dengan Program SPSS. Edisi Kelima. Semarang: Badan Penerbit Undip.

Istijanto (2014) Riset Sumber Daya Manusia. Jakarta: PT. Gramedia Pustaka

Lukiastuti, Fitri, et.al (2020). The Influence of Entrepreneur's Personal Characteristics on SMES Performance Mediated by Entrepreneurial Orientation. International Journal of Psychosocial Rehabilitation. Volume 24 - Issue 8

Robbins, Stephen. P. (2014). Prinsip-prinsip perilaku organisasi. Erlangga. Jakarta.

Sedarmayanti (2015), Sumber Daya Manusia dan Produktivitas Kerja, CV. Mandar Maju, Bandung.

Singgih Santoso (2015). Menguasai Statistik Multivariat. Jakarta: PT Elex Media Komputindo.

Sondang, P. Siagian (2015), Manajemen Sumber Daya Manusia, Bumi Aksara, Jakarta

Sugiyono (2017), Metode Penelitian Administrasi : dilengkapi dengan Metode $R \& D$, Bandung: Alfabeta.

Suharsimi Arikunto (2014). Prosedur Penelitian Suatu Pendekatan Praktek. Jakarta: Rineka Cipta.

Sunarsi, D. (2018). Buku Ajar: Seminar Perencanaan Sumber Daya Manusia. Tangerang Selatan: Asmoro Mediatama

Sunarsi, D. (2018). Pengembangan Sumber Daya Manusia Strategik \& Karakterisrik Sistem Pendukungnya : Sebuah Tinjauan. Jurnal Ilmiah MEA (Manajemen, Ekonomi, \& Akuntansi), 2(3), 178 - 194.

Sunarsi, D. (2019). Seminar Sumber Daya Manusia. Tangerang Selatan: Unpam Press

Sutrisno, Edy. 2016. Manajemen Sumber Daya Manusia. Yogyakarta: Kencana Prenada Media

Sutrisno, S., \& Sunarsi, D. (2019). The Effect of Work Motivation and Discipline on Employee Productivity at PT. Anugerah Agung in Jakarta. Jurnal Ad'ministrare, 6(2), 187-196.

Y Kadarusman, D Sunarsi. (2020). Pengaruh Strategi Penetapan Harga Terhadap Peningkatan Jumlah Siswa Pada SMK PGRI Balaraja. JS (JURNAL SEKOLAH) 4 (3), 213-221

Yuangga, K. D., \& Sunarsi, D. (2018). The Influence of Procrastination and Low Time Management on Student Self Efficacy (at MA Soebono Mantofani). PINISI Discretion Review, 2(1), 85-92. 